\title{
除草剤ピラゾレートの開発
}

\author{
中川昌之, 矢内利明, 谷沢欽次, 山岡 剛 \\ 三共株式会社農薬研究所
}

\section{Development of a New Herbicide, Pyrazolate}

\author{
Masayuki Nakagawa, Toshiaki Yanar, Kinji Tanizawa \\ and Katashi YamaokA \\ Agricultural Chemicals Research Laboratories, Sankyo Co., Ltd., \\ Yasu-cho, Yasu-gun, Shiga 520-23, Japan
}

\begin{abstract}
Pyrazolate [4-(2,4-dichlorobenzoyl)-1,3-dimethyl-5-pyrazolyl p-toluenesulfonate] is a wide spectrum herbicide with excellent selectivity in paddy rice. It has proved successful in controlling both annual and perennial weeds including the problem species of Cyperus, Echinochloa and Sagittaria. The Laboratories set up a research project for perennial weeds control in 1971 and started to screen compounds for several weed species. In 1973, a leading compound was found, which was then optimized through extensive derivatization and evaluation of herbicidal spectrum, selectivity to rice plants, toxicity and environmental safety, cost-performance, etc. The compound thus selected, 4-(2,4-dichlorobenzoyl)-1,3-dimethyl-5-hydroxypyrazole, was so soluble in water that its direct application into paddy fields gave some unfavorable results in biological performance. Accordingly, the compound was derivatizedto mask the hydroxy group aiming at chemical slow release of the herbicidal entity into paddy water. Among a lot of derivatives, pyrazolate was finally selected for its cost-performance, low toxicity to non-target organisms, low impact to the environment. Pyrazolate, with its extremely low solubility along with high hydrolyzability in water, continuously releases the herbicidal entity into paddy water. Its release rate was further optimized to attain maximum herbicidal effect by means of formulation technology such as micronizations of the crystal particles and granular formulations with which the dispersion of ultrafine particles is suppressed to a certain extent. Since the launch of the single active ingredient preparation (Sanbird $\otimes$ ) in 1980 , combination products with many other herbicides manifesting either synergistic or complementary effects have been developed.
\end{abstract}

\section{は じめに}

ピラゾレート（I）は，いままでにないまったく新しい タイプの水田除草郕で, とくにこれまで防除の困難であ った多年生雑草に卓効を示し，かつ，移植水稲はもちろ ん, 薬害を受けやすい直播水稲にも安全に使用できると いう特徵をもつ薬郕である.また, 他の除草剤と相乗性, 相補性の両面で相性がよいため, 昭和 54 年に単剤（サ ンバード囚）が登録されて以来，多くの混合製剤が開発 されている.ピラン゙レートの活性本体は 4- (2, 4 ジクロ
ロベンゾイル)-1,3-ジメチル-5-ヒドロキシピラゾール で，ピラゾレートは，この活性本体をスルホン酸エステ ル化することによって，その有用性を高めたものであ る. 以後, この活性本体を便宜上 DTP (destosyl pyrazolate) と略称する.

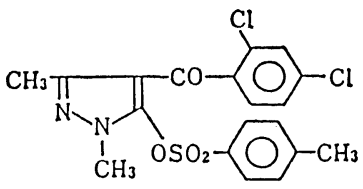


水田に扔ける最初の本格的な化学除草手段として2,4D が登場して以来, より優れた除草剤が相次いで開発さ れ, 昭和 40 年代には水田の最重要雑草である七エをは じめとする一年生雑草の防除手段はほぼ確立されるに至 った。しかし，これらの除草剤は一年生雑草に卓効性が あったが，土畩中の塊茎から発生してくる多年性雑草に 対しては実用的に無力であり，やがてそれらが目立って 繁殖するようになってきた1).

この点に着目して, 当研究所では昭和 46 年に水田多 年生雑草防除に関する研究に着手し, 除草活性検定法の 確立を待って，いわゆるランダムスクリーニングを開始 した. この研究の方向づけがなされてから 2 年後に, 4ベンゾイルピラゾロン誘導体の中から雑草に強い白化作 用を示すリード化合物が見いだされ，多数の誘導体が評 価された結果, 上記の化合物 (DTP) が選抜された: DTP は解離性の水酸基を有するために水溶解度が高く, そのまま使用すると後述のようにいくつかの不都合を生 じたので，まず化学的な徐放化を目的として誘導体を合 成し，次いで製剤的（物理的）にも活性成分を徐放化す ることによりピラゾレートの開発に成功した。

ピラン゙レートの開発研究を特色づけるならば, 次の 3 点に要約される.すなわち，1）未来指向プロジェクト の設定のもとに発足した．2）多年生雑草に化学物質を 有効に働かせるには，その発生生態から必然的にある程 度長い作用期間を要するが, 水田中で化学物質の有効濃 度をある期間保つには徐放化が必須であり，製剂技術だ けで水田での徐放化に成功した農薬の前例はないことを 自らの研究でも文献上でも認識し, 候補化合物の最適化 研究過程でそのことを意識していた. 3）前項に関連し て, 環境化学的研究の重要性を認識し, かなり早い段階 から研究に着手した。

したがって，本稿ではこれらの点に触れながら，主と して選抜研究の経緯, 徐放化製郕拈よび環境化学につい て，その概要を述べる.

\section{選抜研究の経緯}

\section{1. リード化合物の発見}

冒頭に述べたように，本研究は来たるべき時代に備え た明確な目標設定のもとにプロジェクトとして発足した が, 他方, 合成研究者には目標となる多年生雑草防除剂 のよいモデルがなく，ランダムスクリーニングの結果が 唯一の手がかりであった。したがって，合成部門では比 較的自由な䨌囲気の中でイソキサゾール, ピリダジン, オキサジアゾール，ピロール，ピラゾールなど多彩なー テロ環化合物が合成されていた。しかし，その過程の中
Table 1 Herbicidal activity of

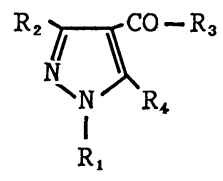

\begin{tabular}{lllll}
\hline \multicolumn{1}{c}{$\mathrm{R}_{1}$} & \multicolumn{1}{c}{$\mathrm{R}_{2}$} & \multicolumn{1}{c}{$\mathrm{R}_{3}$} & $\mathrm{R}_{4}$ & Activity $^{\mathrm{a}}$ \\
\hline $\mathrm{CH}_{3}$ & $\mathrm{CH}_{3}$ & $\mathrm{CH}_{3}$ & $\mathrm{OH}$ & $\mathrm{E}$ \\
$\mathrm{C}_{6} \mathrm{H}_{5}$ & $\mathrm{CH}_{3}$ & $\mathrm{CH}_{3}$ & $\mathrm{OH}$ & $\mathrm{E}$ \\
$\mathrm{CH}_{3}$ & $\mathrm{CH}_{3}$ & $\mathrm{C}_{6} \mathrm{H}_{5}$ & $\mathrm{OH}$ & $\mathrm{D}$ \\
$\mathrm{CH}_{3}$ & $\mathrm{CH}_{3}$ & $2-\mathrm{Cl}-\mathrm{C}_{6} \mathrm{H}_{4}$ & $\mathrm{OH}$ & $\mathrm{A}$ \\
$\mathrm{H}$ & $\mathrm{CH}_{3}$ & $2-\mathrm{Cl}-\mathrm{C}_{6} \mathrm{H}_{4}$ & $\mathrm{OH}$ & $\mathrm{D}$ \\
$\mathrm{C}_{6} \mathrm{H}_{5}$ & $\mathrm{CH}_{3}$ & $2-\mathrm{Cl}-\mathrm{C}_{6} \mathrm{H}_{4}$ & $\mathrm{OH}$ & $\mathrm{C}$ \\
$\mathrm{CH}_{3}$ & $\mathrm{H}$ & $2-\mathrm{Cl}-\mathrm{C}_{6} \mathrm{H}_{4}$ & $\mathrm{OH}$ & $\mathrm{B}$ \\
$\mathrm{CH}_{3}$ & $\mathrm{CH}_{3}$ & $2-\mathrm{Cl}-\mathrm{C}_{6} \mathrm{H}_{4}$ & $\mathrm{SH}$ & $\mathrm{C}$ \\
$\mathrm{CH}_{3}$ & $\mathrm{CH}_{3}$ & $2-\mathrm{Cl}-\mathrm{C}_{6} \mathrm{H}_{4}$ & $\mathrm{CH}$ & $\mathrm{E}$ \\
$\mathrm{CH}_{3}$ & $\mathrm{CH}_{3}$ & $2-\mathrm{Cl}-\mathrm{C}_{6} \mathrm{H}_{4}$ & $\mathrm{NH}_{2}$ & $\mathrm{E}$ \\
\hline
\end{tabular}

a) A: complete kill-E: no effect.

で，ピロール系化合物の中に，効力はきわめて低いもの の，植物に白化作用を示すものが見いだされ，また，テ スアゾン酸 (3-アセチル-5-sec-ブチル-4-ヒドロキシ-3ピロリン-2-オン）拉よび類縁体の稲いもち病防除効果 に関する知見 ${ }^{2)}$ が刺激を与えたことも事実である. Table 1 にはリード化合物が発見された頃までに合成された 4アシルー5-ピラゾロン系化合物が含まれており，上記の ピロール系化合物の部分構造をピラゾールに取り入れる ことによって，新規な生理活性物質を探索した様子の一 端を示すものである。

Table 1 に示すように, 4-アシルピラゾロン誘導体の うち, 当初は主として $\mathrm{R}_{3}$ がフルキル基, $\mathrm{R}_{4}$ が水酸基の ものが合成されたが，それらには除草活性がなかった。 また， $\mathrm{R}_{3}$ をフェニル基に代えたものは除草活性がきわ めて弱く, リード化合物たりうるものではなかった。し かし，同時に合成された $\mathrm{R}_{3}$ が 2-クロルフェニル基のも のは強い活性を示した．このことは, リード化合物の探 索にあたって, 置換基の種類と位置をなるべく広範に選 ぶことの重要性を物語っている。

リード化合物の発見に勇気づけられて，4-ベンゾイル ピラゾロン誘導体を中心に合成展開するとともに，その 知見を他のへテロ環に取り入れた探索研究も行なわれた が，ピラゾール環以外のへテロ環化合物からは優れた除 草活性のものを見いだすことができなかった。

\section{2. 化学構造と生物活性}

4-アシルピラゾロン誘導体の効率的な合成展開を図る ため, まず, $\mathrm{R}_{1}, \mathrm{R}_{2}, \mathrm{R}_{3}$ および $\mathrm{R}_{4}$ の置換基と除草活性 
の関係を検討した ${ }^{3)}$ (Table 1). その結果, $\mathrm{R}_{1}$ と $\mathrm{R}_{2}$ は 低級アルキル基, $\mathrm{R}_{3}$ は置換フェニル基, $\mathrm{R}_{4}$ は水酸基で ある場合に強い活性が期待され， $\mathrm{R}_{3}$ がアルキル基や無 置換フェニル基では活性がなかった． $\mathrm{R}_{3}$ が置換フェ二 ル基である時, $\mathrm{R}_{1}, \mathrm{R}_{2}$ がメチル基であるほうが活性が 強く, フェニル基では活性が低下した，さらに， $\mathrm{R}_{1}$ が 水素の場合は $\mathrm{R}_{3}$ が置換フェニル基であっても活性は著 しく低下した． $\mathrm{R}_{2}$ が水素の時は活性は維持され， $\mathrm{R}_{1}$, $\mathrm{R}_{2}$ は低級アルキル基であれば活性に大きな影響を与え ないことが判明した。 また， $\mathrm{R}_{4}$ は水酸基であることが 必要で, アルキル基, アミノ基, $\mathrm{SH}$ 基等では活性が著 しく低下した.

次に,ピラゾール環の 1 位と 3 位をメチル基に限定し， 4 位ベンゾイル基の置換基を变えた場合 (Table 2), 総 じてオルソ置換体の活性が強く，メタ，パラ置換による 影響は置換基の性質によって異なり，電子吸引性の強い 八ロゲン,ニトロ基ではメタ位よりパラ位の活性が強く, 電子吸引性の弱いメチル基ではメ夕位のほうが活性が強 くなる傾向を示した。この傾向は二置換体でも同様で, 塩素置換についてみると, 活性は 2,4-体 >2,5-体 > 3, 5体 $\fallingdotseq 2,6$-体となった，2,6-置換体の活性が弱いのは塩 素以外の置換基の場合でも同様で，カルボニル基に対す

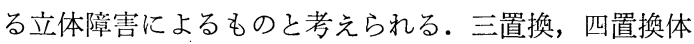
では活性が低下し，混合置換体では 2-Cl-4- $\mathrm{NO}_{2}, 2$, $\mathrm{NO}_{2}-4-\mathrm{Cl}, 2-\mathrm{NO}_{2}-5-\mathrm{CH}_{3}$ 等の置換体が強い活性を示し た.

これらの知見から，フェニル基上の置換基がカルボニ ル基に影響を与えて活性を左右するとともに，4位カル ボニル基と 5 位水酸基が除草活性に必要であることが判 明した。

\section{DTP の選抜}

近年, 生理活性物質の構造活性相関の研究において, 定量的なアプローチが盛んに利用されるようになった が，1960年代にはこの手法はまだ一般的でなかった. 加 うるに, 本研究では生物活性データが多種類の雑草を対 象とする in vivo 試験による離散型データで, Hansch藤田法に代表される統計的手法では有意な結論を導き出 すことが困難なため，研究は試行錯誤的に進めざるをえ なかった．また，リード化合物が発見された後の目標 は，農薬として実用されるために当然であるが，殺草ス ペクトルが広く，選択性の幅が大きく，毒性が低く，生 産コストが低く，環境における安全性の高いものに設定 されたので, 生物試験ではヒエ, 広葉雑草, ホタルイ, ウリカワ, マッバイ, ミズガヤッリ, オモダカに対する 除草活性を検定するとともに, 水稲に対する影響を調べ
Table 2 Herbicidal activity and phytotoxicity<smiles>[X]c1ccc(Oc2c(C)c(C)nn2C)cc1</smiles>

\begin{tabular}{|c|c|c|}
\hline $\mathrm{X}$ & $\mathrm{HR}^{\mathrm{a})}$ & $\mathrm{TR}^{b)}$ \\
\hline $4-\mathrm{CH}_{3}$ & 2.9 & 1 \\
\hline $3-\mathrm{NO}_{2}$ & 2.9 & 1 \\
\hline $3,4-\mathrm{Cl}_{2}$ & 3.0 & 2 \\
\hline $3,4-\left(\mathrm{CH}_{3}\right)_{2}$ & 3.0 & 2 \\
\hline $4-\mathrm{OCH}_{3}$ & 3.0 & 2 \\
\hline $3-\mathrm{Cl}$ & 3.1 & 1 \\
\hline $4-\mathrm{Br}$ & 3.1 & 2 \\
\hline $4-F$ & 3.1 & 1 \\
\hline $3-\mathrm{CH}_{3}$ & 3.1 & 2 \\
\hline $3,5-\mathrm{Cl}_{2}$ & 3.3 & 1 \\
\hline $2,3,4,5-\mathrm{Cl}_{4}$ & 3.3 & 1 \\
\hline $2-\mathrm{OCH}_{3}$ & 3.3 & 2 \\
\hline $4-\mathrm{Cl}$ & 3.4 & 1 \\
\hline $2,3,5-\mathrm{Cl}_{3}$ & 3.4 & 1 \\
\hline $2-\mathrm{COCH}_{3}$ & 3.4 & 1 \\
\hline $4-\mathrm{CN}$ & 3.4 & 2 \\
\hline $3,5-\left(\mathrm{CH}_{3}\right)_{2}$ & 3.6 & 2 \\
\hline $3,5-\left(\mathrm{OCH}_{3}\right)_{2}$ & 3.6 & 1 \\
\hline $2-\mathrm{F}$ & 3.9 & 2 \\
\hline $2-\mathrm{Cl}$ & 4.0 & 2 \\
\hline $2,5-\mathrm{Cl}_{2}$ & 4.0 & 1 \\
\hline $2-\mathrm{CH}_{3}$ & 4.0 & 2 \\
\hline $4-\mathrm{NO}_{2}$ & 4.0 & 2 \\
\hline $3-\mathrm{CH}_{3}-4-\mathrm{NO}_{2}$ & 4.0 & 2 \\
\hline $2-\mathrm{Br}$ & 4.1 & 1 \\
\hline $2,4-\left(\mathrm{CH}_{3}\right)_{2}$ & 4.1 & 2 \\
\hline $3,4-\left(\mathrm{OCH}_{3}\right)_{2}$ & 4.1 & 3 \\
\hline $2-\mathrm{NO}_{2}-5-\mathrm{CH}_{3}$ & 4.1 & 2 \\
\hline $2-\mathrm{Cl}-4-\mathrm{NO}_{2}$ & 4.3 & 2 \\
\hline $2-\mathrm{I}$ & 4.3 & 2 \\
\hline $2,4-\mathrm{Cl}_{2}$ & 4.3 & 2 \\
\hline $2-\mathrm{NO}_{2}$ & 4.3 & 3 \\
\hline $4-\mathrm{SO}_{2} \mathrm{CH}_{3}$ & 4.4 & 3 \\
\hline $2-\mathrm{NO}_{2}-4-\mathrm{Cl}$ & 4.7 & 3 \\
\hline
\end{tabular}

a) Average of herbicidal ratings (HR) to the following weeds: barnyardgrass (Echinochloa crusgalli), broadleaved weeds spontaneously grown in test pot, bulrush (Scirpus juncoides), flatsedge (Cyperus serotinus), omodaka (Sagittaria trifolia), slender spikerush (Eleocharis acicularis) and urikawa (Sagittaria pygmaea).

b) Phytotoxicity rating (TR) to rice seedlings (2.5-leaf stage) transplanted 3 days before application.

\begin{tabular}{|c|c|c|c|c|c|}
\hline HR or TR & 1 & 2 & 3 & 4 & 5 \\
\hline $\begin{array}{l}\text { Effective } \\
\text { dose }(\mathrm{g} / \mathrm{a})\end{array}$ & $\geqq 800$ & $\begin{array}{r}400- \\
200\end{array}$ & $\begin{array}{r}100- \\
50\end{array}$ & $\begin{array}{l}25- \\
12.5\end{array}$ & $\leqq 6.25$ \\
\hline
\end{tabular}


た. Table 2 はそれらの代表例を示すものである.

上記の結果から総合的な活性の強さと薬害について比 較検討し，かつ，毒性および生産コスト面からも試験・ 検討が加えられて, 最終的に $2,4-\mathrm{Cl}_{2}$ 体 (DTP) が選抜 された.このものはリード化合物のベンゼン環の 4 位に もう 1 個塩素を入れただけのものであるが, 結果的には 数百個の誘導体が合成され，多くの項目について試験さ れた。

他方, この研究過程において, 多種類の雑草に卓効を 示すと同時に水稲に対する薬害のおそれのまったくない 化合物を見いだすことはできず，かつ，多年生雑草のだ らだら発生が見られる水田では防除しきれない場面を経 験した. そこで, DTPを後述のように加工することに よって,この問題を解決することにした。

上述のように，この活性化合物の最適化研究は試行錯 誤を中心とする定性的な解析によってなされたが, 後年, 森口らによって開発された適応最小二乗法 $(\operatorname{ALS} \text { 法 })^{4,5)}$ を用いたパターン認識法により，その妥当性が裏付けら れた。たとえば，ノビエに対して強い除草活性を期待す るには, ベンゼン環のオルソ位は疎水性で, かつ電子吸 引性の置換基を有することが望ましく，メ夕位の疎水性 置換基は活性を低下させ，好ましい選択除草活性（とく にヒエとイネの選択性とウリカワなどの多年生雑草に対 する除草効果）を有し，かつ，経済的に合成が容易な化 合物としては DTP が最適であると結論された ${ }^{6,7)}$.

\section{4. 化学的徐放化一ピラゾレートの選抜}

DTP は解離性の水酸基をもっているので，水に対す る溶解度が高い (蒸留水: $415 \mathrm{ppm}$, 田面水に近い $\mathrm{pH} 5.9$ の緩衝液：4500 ppm)。 そのため, DTPを普通に製剤し て使用すると活性成分が急速に溶出し，水稲の幼苗に薬 害を生じたり, 水田系で水の横移動による流亡, 光分解 などにより残効性が短いという欠点がある．水稲に薬害 を起こすことなく，だらだらと発生する多年生雑草を防 除するには, 必要な濃度の DTP を田面水, 土塞中の水 および吸着平衡関係にある土㙵表層にかなり長期間供給 できる製剤が求められた。

このために DTP を吸着剤を用いて徐放化製刋に加工 することを試みたが，実用に耐えるものは得られなかっ た. そこで, DTP の水酸基を化学修飾して, 水田中で 適度なスピードで DTP に杘るような誘導体を求めて精 力的な合成を展開した。それらの誘導体は除草活性, 薬 害, 化学的安定性, 毒性, 製造コストなど種々な点につ いて評価された ${ }^{8)}$.

このようにして，DTPのpートシルエステル（すなわ ちピラゾレート) が最終的に選抜されたが ${ }^{3,9)}$, この化学
的徐放化修飾化合物の選抜にあたっては，修飾基は除草 活性に本質的な役割を演じない補助的なものであること を念頭に置いて，経済性のみならず環境安全面からも検 討を加えた。たとえば，修飾化合物の土水系における分 解性をはじめ, 離脱基の毒性，生分解性などを試験・調 査した結果，ピラゾレートは適当なスピードで DTP と pートルエンスルホン酸に加水分解され，他の分解物を与

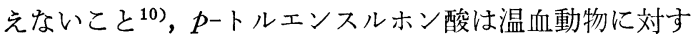
る毒性が低く，かつ，経口投与すると代謝されることな く速やかに尿に排泄されること ${ }^{11)}$ ，土㙵微生物によって 容易に分解され環境安全面からも適していること ${ }^{12,13)}$ などが判断材料としてとり上げられた。

\section{合 成 法}

DTP の類縁化合物である 4-ベンゾイル-5-ピラゾロ ンは公知化合物で，次のような合成法が知られている (Fig. 1).

A法（クライゼン縮合）の収率は低く実用的でない.

$\mathrm{B}$ 法ではアミジン・ $\mathrm{HCl}$ 塩を用いる方法 ${ }^{14)}$ を改良す ることにより，高収率で目的物を合成できるが15)，原料 となるアミジンの合成と反応工程が長いことに難点があ る.

C法 ${ }^{16,17)}$ は反応操作も容易で比較的収率もよく, プロ ジェクト設定当初はこの方法によってスクリーニング用 化合物が合成されたが，副生物が多く，大量生産には適 していない.

しかし，この反応を塩化アルミニウムの存在下で行な うと，高収率で目的物のアルミニウム塩を与え，それを 鉱酸で処理すると目的物が容易に得られる．ただし，触 媒として用いる塩化アルミニウムの量が少ない場合に は，1,3-ジメチル-5-ピラゾロンに互変異性体が存在す るため 5 位 $(O)$ および 2 位 $(N)$ にアシル化された副 生物を生じやすいので，過剰の塩化アルミニウムを必要 とし，その取扱操作上からも経済的に有利な合成法とは いえない。

そこでC法を改良してD法を開発した ${ }^{8)}$.

D法において，まず5-ピラゾロンと 2,4-ジクロロベ ソゾイルクロリドは混和加熱するのみでほぼ定量的に反 応して $\mathrm{HCl}$ が離脱するが, 塩基の存在下では $\mathrm{HCl}$ の遊 離が促進され反応時間が短縮できる．次に，生じた 5-べ ソゾイルオキシピラゾールと 5-ピラゾロンのアニオン が反応すると DTP のアニオンが生成する，反応が進行 すると同時に 5-ピラゾロンが遊離するので，5-ピラゾ ロンのアニオンは少量が反応系に存在すればよく, 実際 には 5-ベンゾイルオキシピラゾールをアルカリ金属炭 
A :<smiles>CN1C2CCN1C2=O</smiles>

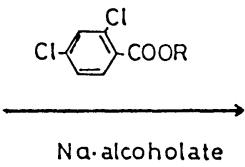<smiles>Cc1nn(C)c(O)c1C(=O)c1ccc(Cl)cc1Cl</smiles>

B :<smiles>CN1CCCC1</smiles><smiles>Nc1ccc(Cl)cc1Cl</smiles><smiles>CN1C2CCN1C2</smiles>

$C:$

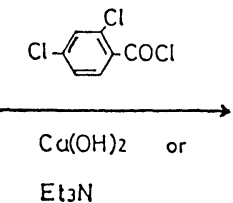<smiles>Cc1nn(C)c(O)c1C(N)c1ccc(Cl)cc1Cl</smiles>

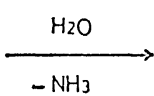<smiles>Cc1nn(C)c2c1c(O)c(C(=O)c1ccc(Cl)cc1)n2C</smiles><smiles>Cc1nn(C)c(O)c1C(=O)c1ccc(Cl)cc1Cl</smiles>

D:<smiles>CN1C2CCN1C2=O</smiles><smiles>CN1CN2C(C(=O)c3ccc(Cl)cc3Cl)=CC2=N1</smiles>

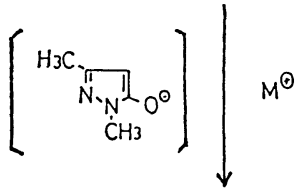<smiles>C1CCCCC1</smiles>

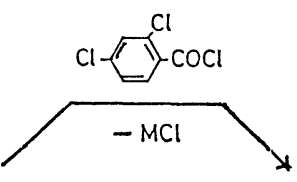<smiles>Cc1nn(C)c(OC(=O)c2ccc(Cl)cc2Cl)c1O[Na]</smiles><smiles>Cc1nn(C)c(C(=O)c2c(Cl)cc(Cl)cc2Cl)c1C(=O)c1c(Cl)ccc(Cl)c1Cl</smiles><smiles></smiles><smiles></smiles>

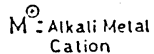

(Pyrazolate)

Fig. 1 Synthetic methods of DTP and pyrazolate.
酸塩の存在下で加熱することにより高収率で DTP 塩が 得られる18).

DTP 金属塩がさらにO-ベンゾイル化された化合物か らも同一反応系で目的化合物が得られる。したがって，
この反応采では等モルの出発原料が最終的にはすべて目 的化合物に変換され，安息香酸を副生しない. ピラゾレートは，この方法で生成した DTP 塩をその ままトシル化することによって，定量的に合成される. 


\section{作 用 特 性 ${ }^{8)}$}

\section{1. 殺草作用}

水中で加水分解して DTP を生成し，それが雑草の幼 芽部打よび根部から吸収されてクロロシスを誘起し, 光 合成を阻害して枯死させる。

殺草活性は雑草の発芽前ないし発芽初期の処理で最も 強く, 葉齢が進むにつれて低下する。

\section{2. 殺草スペクトル}

温暖地のほうが寒冷地に比して効力が高いが，幅広い 殺草スペクトルをもち,一年生イネ科雑草のタイヌビエ, カヤッリグサ科雑草のコゴメカヤッリ，タマガヤッリ， 広葉雑草のアゼナ，アブノメ，コナギおよび多年生雑草 のウリカワ, ホタルイ, オモダカ, ヘラオモダカなどに 強い活性を示す．ミズガヤッリ，マッバイにはやや効力 が弱く,オシュウスズメノヒエ，クログワイに対する効 果は期待できない。

\section{3. 活性の変動}

砂壌土, 植猿土間では効力は变動しないが, 活性成分 の土㙵吸着が強い火山灰土では効力が若干低下寸る場合 がある。

減水深, 湛水深による効力の変動はきわめて少ない が, 十分な水が供給されることが必要で, 土面が露出す ると効力が低下する。

\section{4. 水稲に対する薬害}

移植水稲に対してほとえど薬害がない。通常量の 2 倍 量 $(60 \mathrm{~g} / \mathrm{a})$ 施用しても草丈, 分けつ数ともに無処理区 と同じである。

直播水稲に対しても, 種子の発芽にほとえど影響を与. えず，初期にクロロシスを発現する場合でも生育ととも に軽微となり，実質的に薬害につながることはない。

\section{作 用 機 構}

DTP の除草作用機構に関して, 電子顕微鏡観察によ る葉緑体の形態的变化仼関する研究 ${ }^{19)}$, クロロフィルお よびカロチノイドの生合成阻害に関する研究 $\left.{ }^{20} 23\right)$ が報 告されているが，ここでは 1 例だけを紹介する.

Sandmann ら ${ }^{22)}$ は，暗所でるグルコースと酵母エキス の存在下で生育するイカダモ (Scenedesmus actus) の無 菌培養系に DTP 定添加し, 暗所で 48 時間培養後クロ ロフィルとカロチノイドの生成量を測定した結果, DTP $(5 \mu \mathrm{M}=1.42 \mathrm{ppm})$ はクロロフィルの生合成を阻害する が，カロチノイドの生成には影響を与えないことを報告 している。.またこの研究で同時に比較されたDTP の

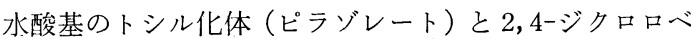

ンゾイル化体はクロロフィル生成量に影響を与えないこ とから，DTP の 5 位水酸基がクロロフィル生合成阻害 に必須と考元られると述べている。この実験では無菌・ 暗黑・短期間の条件下で被験物質の本質的な活性が測定 されている点に特徵があり，上記の知見は， 5 位水酸基 の化学修飾は物性の改良に寄与するが, 活性を高めるた めの本質的な手段ではないとのわれわれの認識を支持す るものである.

\section{徐放化製㓱}

\section{1. ピラゾレートの粒度および水田中における分散性 が除草効果におよ(゙す影響 44,25$)$}

ピラゾレートの水溶解度は $0.05 \mathrm{ppm}$ で, 実用化された 除草剤の中で最も水に溶けにくい化合物と考光られる.

溶解度が低い固体農薬では, 主抄の粒度や主剤粒子の 分散性が生物効果に影響を与えることが多い。そこで, ピラゾレートの粒度と除草効果の関係を検討すると, 流 亡のないポット試験では, 粒度が細かいほうが高い除草 効果を示したが，粒棛による固場試験では，主剂粒度が 粗い場合だけでなく, 細かすぎても除草効果は低下し, 最適な粒度範囲があることが判明した（Fig. 2)。また， 剂型, 粒剤の粒径, 粒の田面水中にお扔る崩壊分散など も除草効果に影響を与元た。

粒の崩壊分散は施肥後の水田では悪くなった，崩壊分 散は各種の電解質の溶液中で劣化したので，水の硬度と の相関を求めた結果, 10 度硬水中で良好な崩壊分散を示 すような粒剤であれば，日本の水田では，顕著な崩壊分 散の劣化が生じることは少ないと考えられた。そこで， これを目標に粒凪の処方を改良した。

\section{2. ピラゾレートの粒度測定法 ${ }^{26)}$}

ピラゾレートの粒度が除草効果に影響することがわか ったので，精度の高い粒度測定法が必要となった。種々

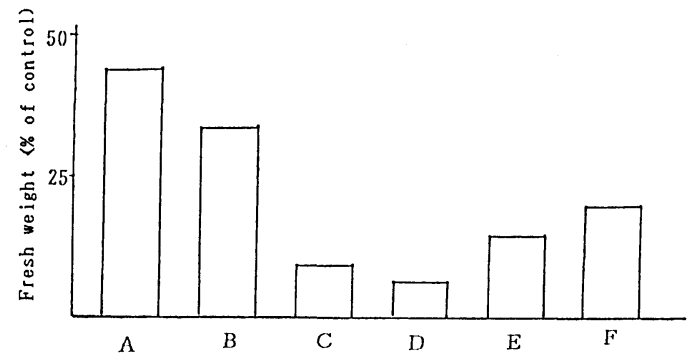

Fig. 2 Herbicidal efficacy of pyrazolate granules in a paddy field.

Surface area of pyrazolate $\left(\mathrm{m}^{2} / \mathrm{g}\right) ; \mathrm{A}: 1.36, \mathrm{~B}$ : 1.76, C: 2.03, D: 2.15, E: 5.13, F: 7.47. 
の粉砕機によりピラゾレートを粉砕し，電子顕微鏡で観 察すると，どの粉砕品にも，0.1 $\mu \mathrm{m}$ 程度の粒子は観察 されたが，それ以下の粒子は見られなかった。ピラゾレ 一トは，通常の粉砕法では $0.1 \mu \mathrm{m}$ 以下の粒子は生じな いか，比較的短時間に，より粗い粒子に成長すると考え られる.そこでュールターカウンターで求めた $>0.794$

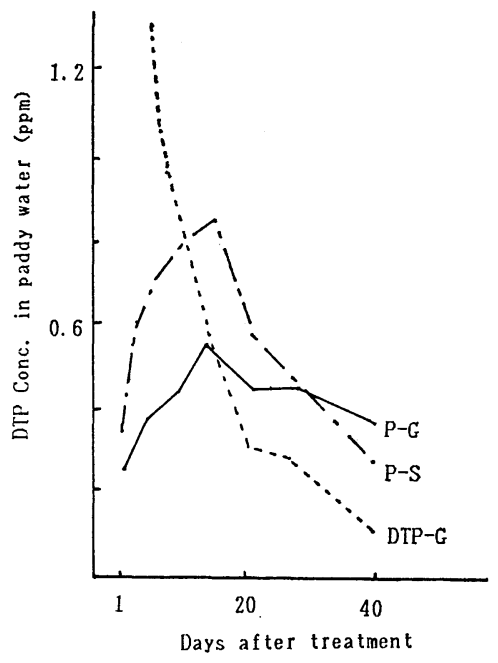

Fig. 3 Changes in DTP conc. in paddy water. P-G: Pyrazolate granules, P-S: Pyrazolate suspension, DTP-G: DTP granules.

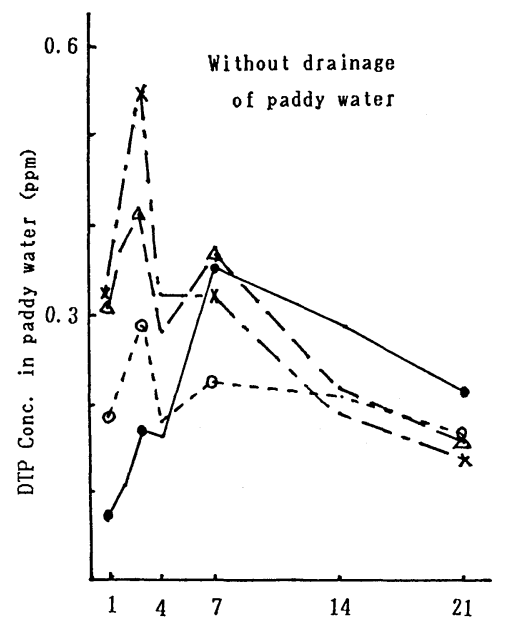

$\mu \mathrm{m}$ 区分の粒度分布と，遠心沈降式光透過法で求めたく $0.794 \mu \mathrm{m}$ 区分の量から全体の粒度分布を求め, 最小粒子

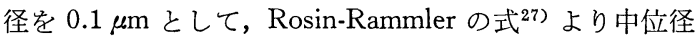
$\left(\mathrm{D}_{50}\right)$ と比表面積 $\left(S_{w}\right)$ を算出する方法を確立した.

3. DTP とピラゾレートの水田中 DTP 生成の違(28) ピラゾレートは田面水中で徐々に溶出し, 活性成分 DTP を生成する。生成した DTP は，一部は土壌に吸 着され，除草効果は，主としてこれらが根から吸収され て発現されると考えられるが，田面水と土塞中の DTP 濃度は平衡関係にあり，前者をモニターすれば除草効果 に関係する DTP の放出性を推定できると考えた。そこ で，DTP 粒剤とピラゾレート製剤とをポットに処理し， 田面水中の DTP 濃度の推移を比較すると（Fig. 3)， DTP 粒剂では, 処理後短時間にDTP が溶出し, 以後急 速に減衰したが，ピラゾレートでは，DTP の生成が抑制 され, 減衰も緩やかであったので, 後半はピラゾレート 区のほうが DTP 区より濃度が高くなった。ピラゾレー トの懸濁剂と粒剤では，粒剂のほうが DTP の生成を抑 制した.

\section{4. ピラゾレートの粒度および剤型と田面水中 DTP 濃度の推移 ${ }^{28,29)}$}

そこで，ピラゾレートの粒度および刻型の異なる製戍 をポットに処理し，流亡のある条件とない条件とで， DTP 濃度をモニターすると（Fig. 4)，DTP の水中濃度

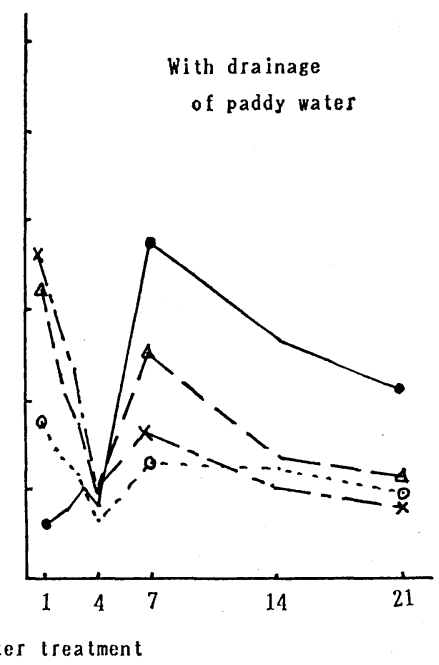

Fig. 4 Changes in DTP conc. in paddy water.

$\bigcirc$ : Pyrazolate suspension A (surface area of pyrazolate; $1.13 \mathrm{~m}^{2} / \mathrm{g}$ ), $\times$ : Pyrazolate suspension B (surface area of pyrazolate; $2.68 \mathrm{~m}^{2} / \mathrm{g}$ ), ๑: Pyrazolate granules B-G prepared from $B, \triangle$ : Pyrazolate microgranules B-MG prepared from B-G. Size of $\mathrm{B}-\mathrm{MG}$ is $0.1-0.5 \mathrm{~mm} \phi$. Pyrazolate was treated at a dose of $1 \mathrm{~kg} / \mathrm{ha}$. Paddy water was diluted with rain on the 4 th day. 
は製戍によって大きく変化した。このうち，ピラン゙レー 卜を比表面積 $2.68 \mathrm{~m}^{2} / \mathrm{g}$ に粉砕し, 10 度硬水中で良好な 崩壊分散を示すように調製した粒剂は, 処理直後の DTP の生成が少ないため流亡が少なく, 排水区でも, 排水中 止後は無排水区とほぼ同じ濃度となった。同じ粒度のピ ラゾレートより調製した眯濁戍や微粒郕では, 流亡が多 く, 排水中止後に DTP 濃度は上昇しなかった。 また, 粒度の粗い懸濁剤は, 試験期間を通して DTP 濃度が低 かった.この結果, 除草効果は粒戍が最もよかった。こ のように, ピラゾレートの粒度および田面水中における 分散は相互に関連しながら DTP の生成に影響を与え る.ピラン゙レートは田植え後の早い時期に用いられるが, この時期は土塞の状態が不安定で, 流亡が生じやすい. その点, DTP の生成が早い䀣濁凨や微粒剂より粒剂の ほうが有利である。しかし，別実験で，粒戍にしてもピ ラゾレートの粒度が粗すぎたり細かすぎたりすると，必 要な時に必要な DTP 濃度が達成されなかった. ピラゾ レートの粒度と粒の崩壊分散が好適に調節されたピラゾ レート粒剤では, ピラン゙レートは長期にわたり, かつ, 完全に溶出することが確かめられた。

\section{5. ピラゾレート粒剤からの DTP 生成機構 ${ }^{28)}$}

ピラゾレートの懸濁郕と粒剂を， 3 段階の薬量で，流 亡のないポットに処理し, DTP 濃度を比較すると, 懸濁 凨の 5 日目では, 薬量の少ない区の濃度が処理薬量に比 して高かったが, 粒郕では, ほぼ施用量に比例する濃度 となった (Fig. 5)。 また，5 日目から 10 日目への濃度 の変化から, 眯濁凨では, ピラゾレートが溶出し尽くし たことが示唆されたが, 粒剛では, 溶出が続いているこ とが示された，粒剤では，主剤は粒剤が崩壊分散した範 囲に,キャリヤーで包まれた状態で密に存在する。この ため, 拡散の源となる表面積が懸濁郕に比べて見掛け上 小さくなり，上記のような濃度比率が維持されると考え られる．主剤が細かければ，粒戍の周辺ではピラゾレー トの高濃度溶液が早く形成されるが，ピラゾレートの溶 解度が低いために溶解しうるピラン゙レートの量は制限さ れる。しかも, 粒剂周辺のピラゾレート濃度が拡散によ って希薄になれば，ピラゾレート粒子が存在するかぎり 順次補充されるから，いわゆる slow release となり，完 全に溶出されることになると考えられる.

このようにして，理論的考察と実験による試行錯誤を 繰り返して現在のピラゾレート粒剤に到達した。ここに 得られた製戍は水田中で 40 日間にわたってDTPを生 成し続ける性質をもっている。このような特徵をもつ製

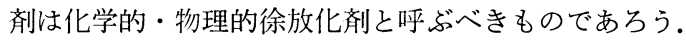

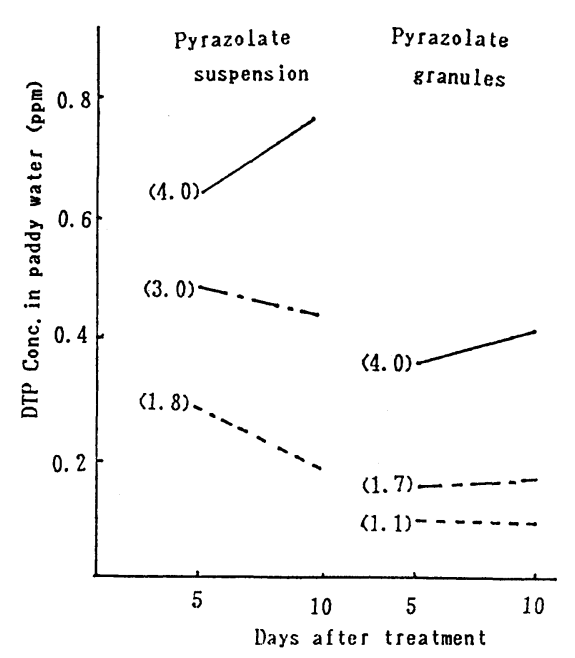

Fig. 5 Changes in DTP conc. in paddy water 5 to 10 days after pyrazolate suspension or granule treatment.

: a.i. $3 \mathrm{~kg} / \mathrm{ha},--$ - a.i. $1.5 \mathrm{~kg} / \mathrm{ha},---$ : a.i. $0.75 \mathrm{~kg} / \mathrm{ha}$. ( ): Ratio of DTP conc. in paddy water (conc. in a.i. $3 \mathrm{~kg} / \mathrm{ha}$ plot $=4.0$ ).

\section{環 境 化 学}

\section{1. 水田における挙動性と残留性 8,30$)$}

ピラゾレートのような水田多年生雑草防除刘は必然的 に作用期間がある程度長いことが必須条件であるが，そ のため一方では環境における残留性や下方移行による地 下水系への流亡性などについて解明しておく必要があ り，ピラン゙レートの水田に扮ける挙動性と残留性につい て開発のかなり早い段階から試験を開始した。

水田に扔けるピラゾレートと DTP の下方移行性につ いては, 昭和 50 年度に各地の農業試験場でピラゾレー 卜粒剂の適用試験が実施された際，試験終了後の区画か ら土㙵を供与していただいて薬物の垂直分布の様相を調 ベた結果，いずれの試験区においてもピラゾレートは表 層にのみ検出され，DTP はピラゾレートに比して若干 移行性が認められたが, 表層から $10 \mathrm{~cm}$ 以下には分布し ていなかった。

水田に打ける挙動性について，もう少しミクロな観点 から調查した結果を Table 3 に示す.ピラゾレート $10 \%$ 粒剤を $3 \mathrm{~kg} / 10 \mathrm{a}$ の割合で人工水田に施用し, 田面水を 毎日 $2 \mathrm{~cm}$ ずつ 15 日間にわたって区画底部から排出し た翌日に田面水と土塨中の薬物を分析した結果，ピラゾ レートと DTP の下方移行による流亡が起こらないとと が確認されるとともに，土袞表層 $(0 \sim 5 \mathrm{~mm})$ に DTP 
の処理層が形成されることが明らかとなった，この現象 はDTP が土壊粒子に吸着されやすいことに基因し，水

Table 3 Leaching of pyrazolate, DTP and $p$ toluenesulfonic acid (PTSA) in a paddy plot 15 days after application of pyrazolate.

\begin{tabular}{ccccl}
\hline & & & $(\mathrm{ppm})$ \\
\hline \multicolumn{2}{c}{ Chemical } & Pyrazolate & DTP & PTSA \\
\hline Paddy water & 0.01 & 0.89 & n.d. \\
\hline Soil & $0-5 \quad(\mathrm{~mm})$ & $\left.18.04^{\mathrm{a}}\right)$ & $\mathbf{8 . 7 8}$ & n.d. \\
& $5-15$ & 0.43 & 0.46 & n.d. \\
& $15-25$ & n.d. $^{\text {b) }}$ & n.d. & n.d. \\
& 25-35 & n.d. & n.d. & n.d. \\
\hline
\end{tabular}

a) The theoretical value of the initial concentration in this layer of soil is $60 \mathrm{ppm}$.

b) n.d.: not detected ( $<0.02 \mathrm{ppm})$.

Paddy water was drained daily from the basal part of the plot at 2-cm/day for 15 days and sampling was conducted at the next day.
田土塞の DTP 吸着容量は大きく, しかも吸着は可逆的 で, 土䁃と土壌間隙水中の DTP 濃度は, 土性と地水温 に応じて，ある一定の平衡関係にあることが判明した。 この DTP の土塨吸着性が水田における薬物の流亡を妨 げるとともに効力の持続性に寄与していることは明らか である，また，ピラゾレートから生成する $p$-トルエン スルホン酸はきわめて速く分解し, 残留性のまったくな い化合物であることがわかる。

ピラゾレート剤の連年施用における土䁃および稲収穫 物への残留蓄積性試験（いわゆる永年蓄積性試験）も開 発段階から有底人工水田を用いて試験を開始し, 上市後 は全国各地の農家のご協力を得て戋場実態調査を行なっ た. Table 4 はピラゾレートと DTP の土壌残留調査結 果をまとめたものである。累積残留濃度は表層 $10 \mathrm{~cm}$ に おけるピラゾレートと DTP の残留量 $(\mathrm{ppm} w / \mathrm{v})$ の合 計で示してあるが，その内訳は DTP が大部分を占めて いる。なお, DTP から 1 個の塩素原子が離脱したモノ クロル体は検出されなかった. ピラゾレートの 1 回施用 量から求めた理論值に対する累積残存率（各連用年数後

Table 4 Residues of pyrazolate and DTP in paddy fields after periodic applications.

\begin{tabular}{|c|c|c|c|c|c|c|}
\hline Location & Soil origin & $\begin{array}{c}\text { Dosage }^{\mathrm{a})} \\
(\mathrm{kg} / 10 \mathrm{a})\end{array}$ & $\begin{array}{l}\text { Periodic } \\
\text { application } \\
\text { (year) }\end{array}$ & $\begin{array}{c}\text { Packed } \\
\left.\text { volume }{ }^{b}\right) \\
\left(\mathrm{cm}^{3} / \mathrm{g}\right)\end{array}$ & $\begin{array}{l}\text { Cumulative } \\
\text { residues }{ }^{\mathrm{c}} \\
(\mathrm{ppm} \mathrm{w} / \mathrm{v})\end{array}$ & $\begin{array}{l}\text { Ratio } \\
(\%)^{d)}\end{array}$ \\
\hline \multicolumn{7}{|c|}{ Pot plot $\left(0.3-1.0 \mathrm{~m}^{2}\right)$} \\
\hline Shiga & Alluvial & 3 & 4 & 1.5 & 0.27 & 9.0 \\
\hline$" \prime$ & $\prime \prime$ & 4 & 9 & 1.5 & 0.63 & 15.8 \\
\hline$\prime \prime$ & " & 5 & 8 & 1.5 & 0.92 & 18.4 \\
\hline Shiga & Volcanic ash & 3 & 5 & 1.9 & 0.78 & 26.0 \\
\hline$" 1$ & $" \prime$ & 3 & 6 & 1.9 & 0.69 & 23.0 \\
\hline \multicolumn{7}{|l|}{ Paddy field } \\
\hline Hokkaido & Alluvial & 3 & 3 & 1.6 & 0.33 & 11.0 \\
\hline Iwate & Volcanic ash & 3 & 5 & 2.3 & 0.89 & 29.7 \\
\hline Tochigi & $\prime \prime$ & 3 & 5 & 2.2 & 1.31 & 43.7 \\
\hline$" \prime$ & $\prime \prime$ & 3 & 5 & 2.9 & 0.80 & 26.7 \\
\hline$" \prime$ & $"$ & 3 & 5 & 2.1 & 0.23 & 7.7 \\
\hline Shizuoka & Alluvial & 3 & 5 & 2.2 & 0.71 & 23.7 \\
\hline$" \prime$ & $" \prime$ & 3 & 5 & 2.1 & 0.89 & 29.7 \\
\hline Shiga & $\prime \prime$ & 3 & 4 & 1.4 & 0.41 & 13.7 \\
\hline 11 & $" \prime$ & 3 & 7 & 1.4 & 0.64 & 21.3 \\
\hline Saga & " & 3 & 5 & 1.7 & 0.38 & 12.7 \\
\hline Miyazaki & Volcanic ash & 3 & 5 & 2.1 & 0.26 & 8.7 \\
\hline Kagoshima & " & 3 & 5 & 2.3 & 0.08 & 2.7 \\
\hline
\end{tabular}

a) A granular formulation of $10 \%$ pyrazolate was applied.

b) Sedimentation volume of soils ( $\mathrm{ml}$ ) to weight of soils on oven-dry basis ( $\mathrm{g}$ ).

c) Total residues (ppm, weight/volume) of pyrazolate and DTP in soil of $10 \mathrm{~cm}$ depth after periodic applications.

d) Cumulative residues to the theoretical value based on a single dosage of pyrazolate [e.g., $3 \mathrm{ppm}$ at $3 \mathrm{~kg} / 10 \mathrm{a}$ ]. 


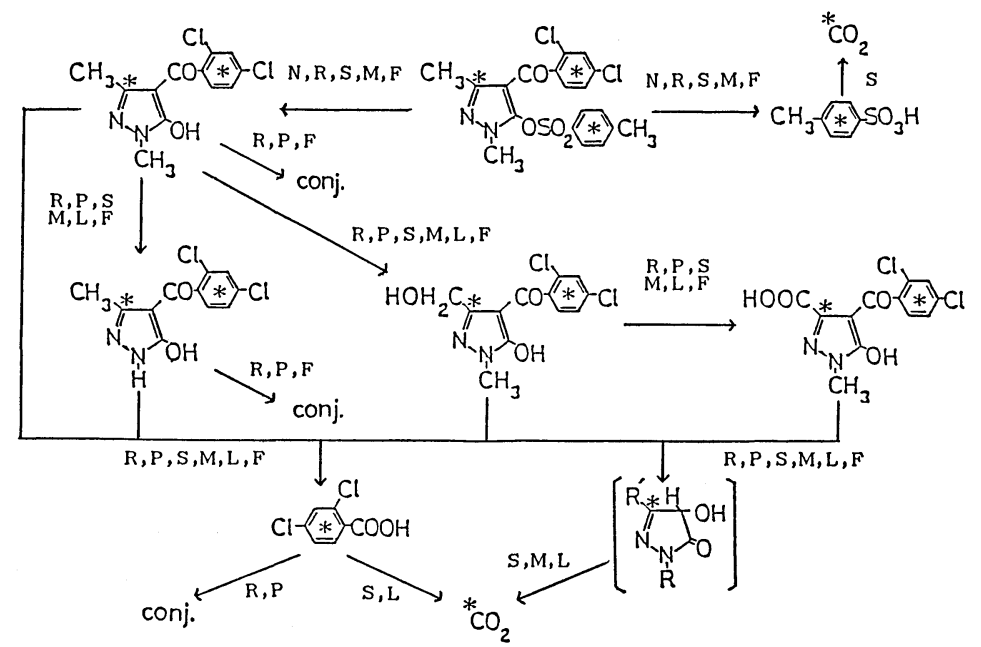

Fig. 6 Degradation and metabolism of pyrazolate in the environment.

$\mathrm{N}$ : nonbiological, $\mathrm{R}$ : rat, $\mathrm{P}$ : rice plant, $\mathrm{S}$ : soil, $\mathrm{M}$ : soil microorganism, L: sunlight, F: fish \& shellfish, Conj.: conjugate.

の残留濃度の比）は，杤木県の一围場を除き，いずれも $30 \%$ 以下であり, 蓄積傾向は認められなかった。また， 残存率と試験地域および土性との間に明確な相関関係は 認められなかった。

稲収穫物中のピラゾレートおよび主要代謝分解物の残 留量はいずれも検出限界以下であり，連年施用によって 残留レベルが上昇する傾向はまったく見られなかった.

\section{2. 魚介類における生物濃縮性 ${ }^{31)}$}

${ }^{14} \mathrm{C}$ 標識化合物を用いて測定した濃縮倍率は次のとお りで, 排泄も速やかであり, 環境生物を通じて食物連鎖 に入る可能性は事実上ほとんどないと考えてよい.

$\begin{array}{lll}\text { グッピー } & \text { ピラゾレート } & 3 \sim 12 \\ & \text { DTP } & <15 \\ & \text { p-トルェンスルホン酸 } & <1 \\ \text { アサリ貝 } & \text { ピラゾレート } & 2.3 \\ & \text { DTP } & 2.3\end{array}$

ピラゾレートの生物濃縮性がオクタノール・水分配係 数 $\left(\log K_{\mathrm{ow}}\right.$ : 3.71$)$ や水溶解度 $(0.05 \mathrm{ppm})$ からの予測 に反してきわめて低いのは，ピラゾレートが生物的にも 非生物的にも容易に極性化合物に加水分解されるためで あり，この生物濃縮性に関する知見は結果論として得ら れたものではなく, DTP の化学的徐放化剤の選抜過程 における幅広い観点からの議論と予測の帰結であること を付記して扮きたい。

\section{3. $の$ 他}

哺乳動物 $(\text { ラット })^{32)}$, 植物 (水稲) ${ }^{33)}$, 土塨微生物 ${ }^{34)}$ における代謝ならびに土袞中での分解 ${ }^{35}$, 光分解 ${ }^{36)}$ に関
する研究結果を総合して，ピラゾレートの環境における 代謝分解経路を Fig. 6 に示す.

いわゆる生物濃縮性試験としては, 前述の魚介類に加 えて, 哺乳動物における長期毒性試験終了後の各臓器に ついてピラゾレートおよび DTP の残留量を測定した が，蓄積性はまったく認められなかっだ)。

${ }^{14} \mathrm{C}-\mathrm{DTP}$ を水耕栽培した水稲苗に処理すると, 根部か ら吸収されて速やかに代謝され，DTP と代謝物の双方 とも大部分は根部に留まり, 地上部への移行性は低かっ た ${ }^{33)}$. 水稲地上部への移行性が低いことについては, ${ }^{14} \mathrm{C}$-ピラゾレートを処理したポット試験においても同様 で35)，このことが稲収穫物への残留性の低い要因と考え られる，他方，なぜ水稲にだけ薬害が際立って少ないの かという選択性機構については現在も研究中であるが, 水稲の DTP 代謝能が高く, かつ, 代謝物の除草活性がい ずれもきわめて低いことが主要因の一つと考えられる。

\section{安全性}

ピラゾレートは哺乳動物, 魚類, その他の環境生物に 安全性が高く8)，土㙵微生物相に与える影響はほとえど ないことも確かめられており ${ }^{37)}$ ，環境化学的知見と相挨 って，環境におよぼすインパクトのきわめて低い薬剤で あるといえよう。

\section{おわりに}

ピラゾレートの最も優れた特徴は, 多年生雑草にも有 効な殺草スペクトルの広さと，水稲に対してきわめて薬 
害が少なく直播水稲にも使用でき，しかも他の除草刜と 相乗的, 相補的に相性がよいことで, その特徵を生かし た混合剤が多数実用化されて扣り，かつ，現在も開発試 験中である.

プロジェクト設定時点から今日の製品群に育て上げる まで, ピラゾレートの研究開発に携わった人の数はきわ めて多く，そのことは「ピラゾール系除草剤の開発と製 造法の確立」に関して, 三共株式会社が事業体として, 第 32 回大河内記念生産賞を受賞したことにも現われて いる.

ピラゾレートの開発を音楽にたとえれば，主演者に合 奏する型式の協奏楽ではなく, 指揮者の方向づけのもと に全員がロマンを抱いて力奏した交響楽であった，その 中の一奏者であったわれわれがこの度の受賞者として選 ばれたことを誠に光栄に存ずるとともに，その名誉は指 揮者をはじめオーケストラ全員に帰属すべきものと存ず る次第である.

ピラゾレート剂の開発上市に当たっては，日本植調協 会をはじめ，国立および各都道府県農業研究機関の熱意 あるご指導とご支援を賜わった，関係各位に心から感謝 の意を表します。

\section{引用 文 献}

1）植木邦和：農薬一デザインと開発指針,山本 出・ 深見順一編，ソフトサイエンス社， pp. 775-777， 1979

2）佐藤善司 - 岩崎成夫 - 室 秀輝 - 野副重男 - 奥田 重信：日植病報 38, 204 (1972)

3) T. Konotsune, K. Kawakubo \& T. Yanai: “Advances in Pesticide Science," ed. by H. Geissbühler, Part 2, Pergamon Press, New York, pp. 94-98, 1979

4) I. Moriguchi \& K. Komatsu: Chem. Pharm. Bull. 25, 2800, 3440 (errata) (1977)

5) I. Moriguchi, K. Komatsu \& Y. Matsushita: $J$. Med. Chem. 23, 20 (1980)

6) T. Matsui, T. Konotsune, K. Kawakubo \& M. Ishida: "IUPAC Pesticide Chemistry, Human Welfare and the Environment," ed. by J. Miyamoto \& P. C. Kearney, Vol. 1, Pergamon Press, New York, pp. 327-332, 1983

7）石田三雄・松井孝司：農薬の生有機化学と分子設 計, 江藤守総編, ソフトサイエンス社, pp. 519537,1985

8）石田三雄・松井孝司 - 矢内利明 - 川久保克彦 - 本 間豊邦・谷沢欽次・中川昌之・奥平洋己：三共研 年報 36, 44 (1984)

9）此常卓男 - 川久保克彦：特公昭 54-36648（1979）

10) K. Yamaoka, M. Nakagawa \& M. Ishida: J. Pesticide Sci. 12, 209 (1987)
11) J. Dreyfuss, J. M. Shebosky \& J. J. Ross, Jr.: Toxicol. Appl. Pharmacol. 20, 548 (1971)

12) R. B. Cain \& D. R. Farr: Biochem. J. 106, 859 (1968)

13) M. J. Ripin, K. F. Noon \& T. H. Cook: Appl. Microbiol. 21, 495 (1971)

14) W. Müller, U. Kraatz \& F. Korte: Chem. Ber. 106, 332 (1973)

15）城島輝臣 - 竹柴英雄 - 富田和男 - 此常卓男：特公 昭 59-24146 (1984)

16) B. S. Jensen: Acta Chem. Scand. 13, 1668 (1959)

17) A. S. Sarenko, I. Yakvitko \& L. S. Efros: Khim. Geterotsikl. Soedin. No. 6, 799 (1972)

18）松井孝司・飛塚淳三・矢内利明 - 比常卓男：特公 昭 58-35188 (1983)

19）前田英三・前田和子 - 小川正巳 - 石田三雄：雑草 研究 29 別号, 第 23 回講演会講演要旨, p. 131 (1984)

20) K. Kawakubo, M. Shindo \& T. Konotsune: Plant Physiol. 64, 774 (1979)

21）竹松哲夫 - 近内喊登・竹内安智 - 磯部和正：雑草 研究 27 別号, 第 21 回講演会講演要旨, p. 93 (1982)

22) G. Sandmann, H. Reck \& P. Böger: J. Agric. Food Chem. 32, 868 (1984)

23) T. Soeda \& T. Uchida: Pestic. Biochem. Physiol. 29, 35 (1987)

24）谷沢欽次 - 藤本昌彦・川保克彦 - 河西史人 - 本 間豊邦・中村利家：農薬誌 12,635 (1987)

25）谷沢欽次・本間豊邦・河西史人 - 川久保克彦 - 中 村利家：農薬誌 12, 643 (1987)

26）谷沢欽次・河西史人：三共研年報 37, 121（1985）

27）桑原好孝：粉体工学研究会誌 10(4), 223 (1973)

28）谷沢欽次 - 本間豊邦 - 河西史人 - 中村利家 - 石田 三雄：農薬誌 13,77 (1988)

29）谷沢欽次 - 川久保克彦・河西史人 - 中村利家 - 石 田三雄：農薬誌 12, 651 (1987)

30) K. Yamaoka, M. Tohjigamori, Y. Tsujino, M. Nakagawa \& M. Ishida: J. Pesticide Sci. 13, 261 (1988)

31) T. Ueda, S. Sadakane, K. Yamaoka, M. Nakagawa \& M. Ishida: J. Pesticide Sci. 13, 85 (1988)

32) M. Ando, T. Yanai, K. Yamaoka, M. Nakagawa \& M. Ishida: J. Pesticide Sci. 12, 461 (1987)

33) M. Ando, K. Yamaoka, Y. Shigematsu, M. Nakagawa \& M. Ishida: J. Pesticide Sci. submitted

34）加藤重博 - 中神和人 - 中西逸朗・高日幸義：未発 表

35) K. Yamaoka, Y. Shigematsu, M. Ando, M. Tohjigamori, M. Nakagawa \& M. Ishida: J. Pesticide Sci. submitted

36) K. Yamaoka, Y. Tsujino, M. Ando, M. Nakagawa \& M. Ishida: J. Pesticide Sci. 13, 29 (1988)

37）高日幸義・川久保克彦 - 中西逸朗 - 中神和人 - 本 間豊邦：三共研年報 38, 95 (1986) 